Article

\title{
Anti-Ageing Effects of Sonchus oleraceus L. (pūhā) Leaf Extracts on $\mathrm{H}_{2} \mathrm{O}_{2}$-Induced Cell Senescence
}

\section{Zong-Quan Ou ${ }^{1}$, Thomas Rades ${ }^{2}$ and Arlene McDowell ${ }^{1, *}$}

1 School of Pharmacy, University of Otago, Dunedin 9056, New Zealand;

E-Mail: zongquan.ou@otago.ac.nz

2 Department of Pharmacy, University of Copenhagen, Copenhagen 2100, Denmark;

E-Mail: thomas.rades@sund.ku.dk

* Author to whom correspondence should be addressed; E-Mail: arlene.mcdowell@otago.ac.nz; Tel.: +64-3-479-7145; Fax: +64-3-479-7034.

Academic Editor: Marcello Iriti

Received: 21 January 2015 / Accepted: 3 March 2015 / Published: 12 March 2015

\begin{abstract}
Antioxidants protect against damage from free radicals and are believed to slow the ageing process. Previously, we have reported the high antioxidant activity of $70 \%$ methanolic Sonchus oleraceus L. (Asteraceae) leaf extracts. We hypothesize that S. oleraceus extracts protect cells against $\mathrm{H}_{2} \mathrm{O}_{2}$-induced senescence by mediating oxidative stress. Premature senescence of young WI-38 cells was induced by application of $\mathrm{H}_{2} \mathrm{O}_{2}$. Cells were treated with $S$. oleraceus extracts before or after $\mathrm{H}_{2} \mathrm{O}_{2}$ stress. The senescenceassociated $\beta$-galactosidase (SA- $\beta$-gal) activity was used to indicate cell senescence. $S$. oleraceus extracts showed higher cellular antioxidant activity than chlorogenic acid in WI-38 cells. S. oleraceus extracts suppressed $\mathrm{H}_{2} \mathrm{O}_{2}$ stress-induced premature senescence in a concentration-dependent manner. At 5 and $20 \mathrm{mg} / \mathrm{mL}$, S. oleraceus extracts showed better or equivalent effects of reducing stress-induced premature senescence than the corresponding ascorbic acid treatments. These findings indicate the potential of S. oleraceus extracts to be formulated as an anti-ageing agent.
\end{abstract}

Keywords: Sonchus oleraceus; antioxidants; leaf extracts; caffeic acid derivatives; CAA; senescence; anti-ageing 


\section{Introduction}

Ageing or senescence is a complex and inevitable biological process, which is not only attributed to individual genetic variation but also to external factors such as environmental conditions, nutrition, alcohol and diseases [1-4]. There are three theories that have been proposed to explain ageing: genetic, neuroendocrine and damage-accumulation theories, which are all important and interrelated [5]. Of these theories, the most widely accepted is the free radical theory that ageing and its related diseases result from accumulated oxidative damage to cell constituents and tissues caused by excessive exposure to free radicals [6]. Reactive species are generated during normal cell metabolism [7] or to protect humans from immediate death from infections [8]. These reactive species can cause lipid peroxidation, denature proteins and fragment DNA due to oxidative stress, and further increase the mutation rate, especially when the antioxidant defenses cannot remove the excess free radicals [5,7,8]. Increasing oxidative stress is commonly associated with ageing and age-related diseases [9].

Antioxidants, which mediate the imbalance between intracellular antioxidant defenses and oxidative damage by reducing the reactive oxygen species (ROS) levels, are believed to be able to reduce stress-induced premature senescence or slow down replicative senescence. Investigations with ascorbic acid and vitamin E [10-13], or plant-derived antioxidants [14-17] confirm this claim. Due to the reported carcinogenesis and hepatoxicity of synthetic antioxidants [18], antioxidants from natural origins are preferable in applications for medications and food additives. Both normal human fibroblasts and $\mathrm{H}_{2} \mathrm{O}_{2}$-stressed fibroblasts experienced an extended lifespan in the presence of cyanidin, the most prevalent anthocyanin in plants [19]. Likewise in in vivo studies, protocatechuic acid from Alpinia oxyphylla fruits successfully enhanced endogenous antioxidant levels and therefore their activity, and down-regulated malondialdehyde (a biomarker of ageing) in aged rats [14].

Cellular senescence can occur due to failure in cell proliferation, or exposure to a variety of cellular stresses, such as oxidizing or DNA damaging agents, or expression of activated oncogenes [3,20]. A variety of cellular senescence features have been identified, amongst which are cellular morphology [2,21], telomere length $[2,22]$, gene expression [23] and senescence-associated $\beta$-galactosidase (SA- $\beta$-gal) activity $[24,25]$. During ageing, senescence-related genes can be over-expressed to induce senescent morphogenesis [23]. Many senescence-associated, over-expressed proteins can be utilized as biomarkers, such as transforming growth factor- $\beta 1$, ICFBP-3 mRNA, p16 tumor suppressor protein and $\beta$-galactosidase [23-25]. $\beta$-Galactosidase is a collective name for enzymes that cleave non-reducing $\beta$-D-galactose residues from glycoproteins, sphingolipids and keratin sulphate in $\beta$-D-galactosides [20]. In senescent cells, the over-expression of $\beta$-galactosidase enables the detection of $\beta$-galactosidase activity at sub-optimal $\mathrm{pH}[3,24]$. This enzyme activity is not detectable in actively proliferating cells. There are two main methods to measure the SA- $\beta$-gal activity [3]. It can be cytochemically or histochemically detected using the chromogenic substrate 5-bromo-4-chloro-3-indoyl $\beta$-D-galactopyranoside. SA- $\beta$-gal positive (blue-stained) cells are manually counted and expressed as the percentage of total cell population [24]. The cytochemical assay is simple and allows detection in tissue samples. On the other hand, it is subjective and the procedure is time-consuming. The second method is fluorescence-based using the fluorogenic substrates 5 -dodecanoylaminofluorescein-di- $\beta$-D-galactopyranoside $\left(\mathrm{C}_{12} \mathrm{FDG}\right)$ or fluorescein-di- $\beta$-D-galacto-pyranoside (FDG) lysosome alkalinizaiton. SA- $\beta$-gal positive activity can be detected and quantified using a flow cytometer, microfluidics analyzer or fluorescence microscope [3]. 
The fluorescence-based methods permit quantitative measurement of single cells in the population. Compared with cytochemical assays, fluorescent assays are more sensitive and accurate with higher throughput.

Sonchus oleraceus L. (family Asteraceae) is well-known for its high content of antioxidants and antioxidant activity [26-30]. In New Zealand, it is commonly known as pūhā, where it is a dietary and traditional medicinal plant in Māori culture. We have previously identified three major antioxidants in methanolic leaf extracts of $S$. oleraceus: caftaric acid, chlorogenic acid and chicoric acid, with chicoric acid having the highest concentration [31]. To the authors' knowledge, there is no report of the potential anti-ageing effects of $S$. oleraceus leaf extracts, neither in vitro nor in vivo. We have previously shown that $S$. oleraceus leaf extracts are absorbed into cells in vitro and can exert an antioxidant effect, but it remains unclear if the antioxidants in $S$. oleraceus leaves are beneficial for cells in combating oxidative senescence. Demonstration of antioxidant activity in healthy cells is a useful screening method for the bioactivity of novel compounds, however to be useful as therapeutic agents, these compounds must show effects in a disease state. Herein, we investigated the effects of $S$. oleraceus leaf extracts on $\mathrm{H}_{2} \mathrm{O}_{2}$-stressed human lung fibroblasts. SA- $\beta$-gal activity was used as the biomarker indicating premature senescence of the cells.

\section{Results and Discussion}

\subsection{Cell Viability}

WI-38 cells retained greater than $90 \%$ viability after $3 \mathrm{~h}$ incubation with leaf extracts from $S$. oleraceus (Figure 1a). It is assumed that concentrations of the leaf extract lower than $20 \mathrm{mg} / \mathrm{mL}$ would also be non-toxic. With addition of $\mathrm{H}_{2} \mathrm{O}_{2}$, cell viability decreased with increasing concentration (Figure $1 b$ ). Therefore, a concentration of $100 \mu \mathrm{M}$ or lower $\mathrm{H}_{2} \mathrm{O}_{2}$ was chosen for further experiments.

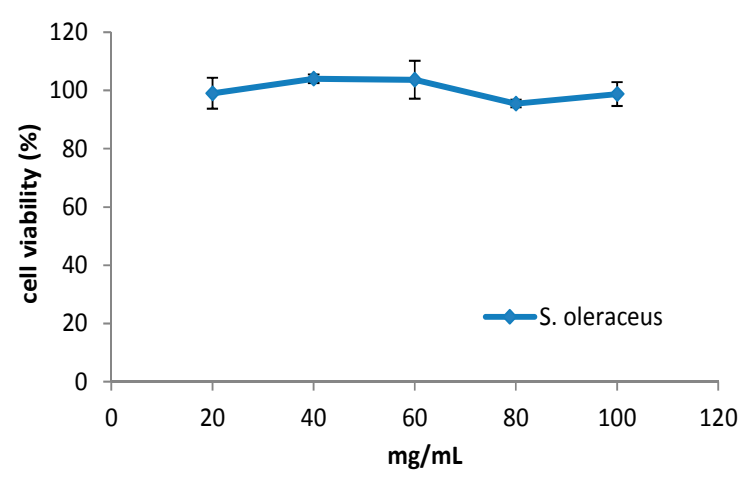

(a)

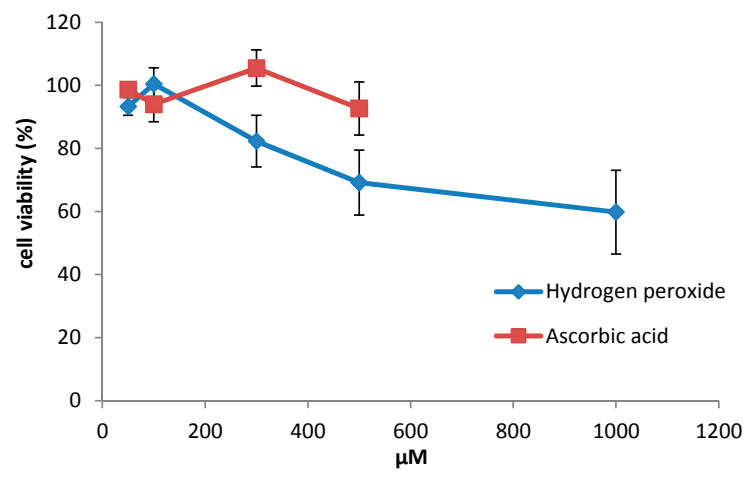

(b)

Figure 1. Viability of WI-38 cells after treatment with (a) various concentrations of S. oleraceus leaf extracts from 20 to $100 \mathrm{mg} / \mathrm{mL}$ and (b) $50-1000 \mu \mathrm{M} \mathrm{H}_{2} \mathrm{O}_{2}$ or $50-500 \mu \mathrm{M}$ ascorbic acid for $3 \mathrm{~h}$. Data represent triplicate treatments and are expressed as mean $\pm \mathrm{SD}$ $(n=3)$. 


\subsection{Cellular Antioxidant Activity (CAA) Assay}

The CAA assay quantifies the antioxidant activity by measuring the ability of applied compounds to prevent oxidation in cells. In the CAA assay, DCFH-DA is converted to fluorescent DCF by peroxyl radicals [32]. The fluorescence intensity is proportional to the ROS concentration in the cells. The curves in the Figure 2 indicate the formation of the fluorescent DCF over $60 \mathrm{~min}$. The flatter the curve, the less DCFH is oxidised. Using the CAA assay we found that the oxidation of DCFH to DCF was reduced by S. oleraceus leaf extracts in a dose-dependent manner within the concentration range of $1-25 \mathrm{mg} / \mathrm{mL}$ (Figure 2a). Intracellular ROS due to normal cell metabolism also would cause the oxidation of DCFH. However, the present results are processed data after subtracting a blank (oxidation of DCFH by normal cell metabolism) from raw data. Chlorogenic acid also decreased the formation of fluorescence with increasing concentration from 50 to $500 \mu \mathrm{M}$ (Figure 2b). For the two other major compounds identified in $S$. oleraceus leaf extracts, caftaric acid and chicoric acid, the fluorescence was completely quenched (data not shown). Comparing $S$. oleraceus extracts with chlorogenic acid, $S$. oleraceus leaf extracts showed much higher activity with an $\mathrm{EC}_{50}$ value of $2.85 \mathrm{mg} / \mathrm{mL}(50.16 \mu \mathrm{M}$ equivalent of total concentration of the three key antioxidants) than that of chlorogenic acid with an EC50 value of $166.34 \mu \mathrm{M} .1 \mathrm{mg} / \mathrm{mL}$ S. oleraceus leaf extracts and $50 \mu \mathrm{M}$ chlorogenic acid showed similar inhibition of the fluorescence (Figure 2). This also can be confirmed by the CAA units obtained from the CAA assay (Figure 3). The CAA unit from the CAA assay indicates the intra-cellular activity of the samples. $1 \mathrm{mg} / \mathrm{mL}$ of $S$. oleraceus leaf extracts (containing $17.6 \mu \mathrm{M}$ of the three key active compounds in total) exhibited a trend of higher activity, with $29.44 \pm 7.44$ CAA units, than that of $50 \mu \mathrm{M}$ chlorogenic acid (31.34 \pm 1.79 CAA units) (Figure 3 ). Within the concentration ranges studied, S. oleraceus leaf extracts showed higher potency than chlorogenic acid alone.

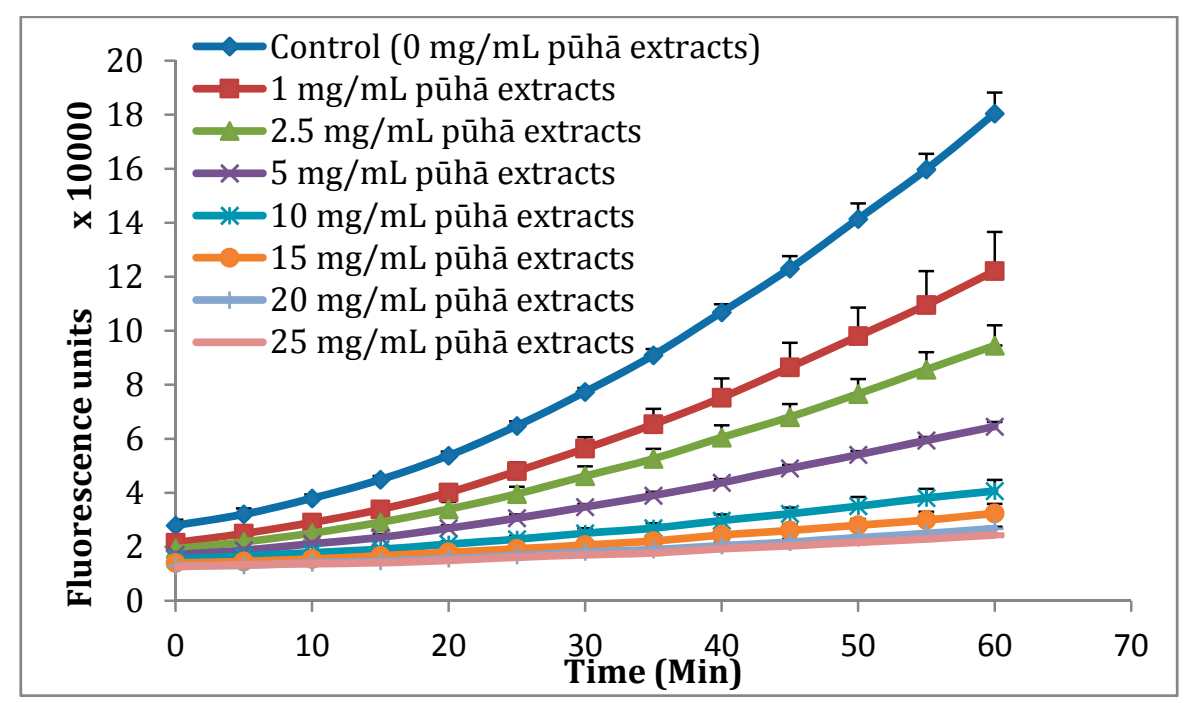

(a)

Figure 2. Cont. 


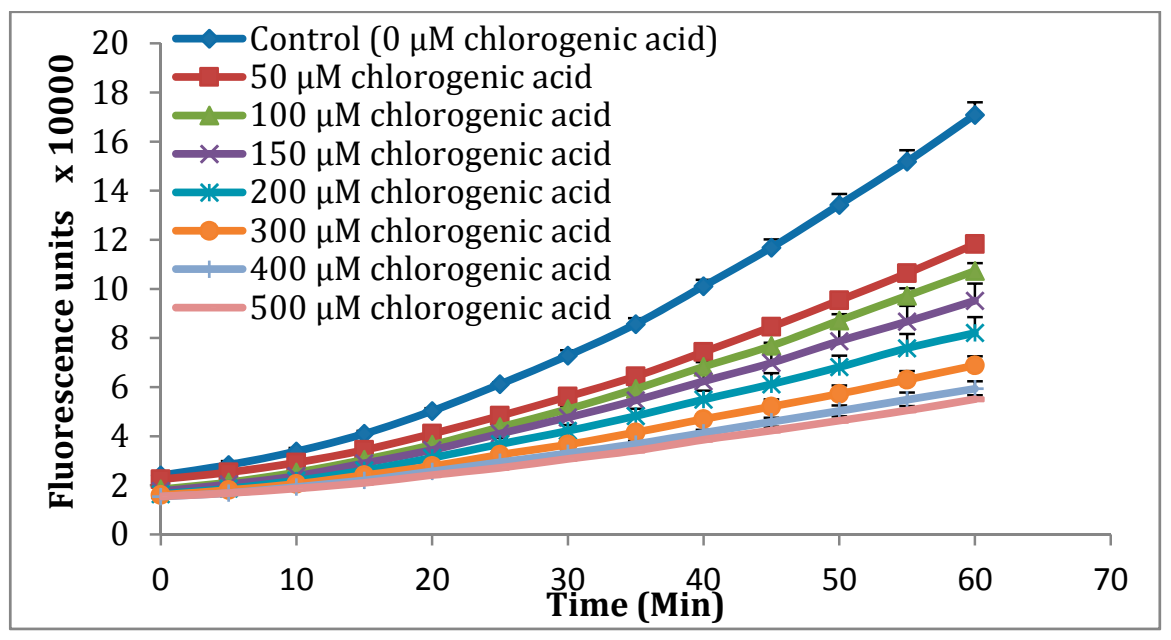

(b)

Figure 2. Peroxyl radical-induced oxidation of DCFH to DCF in WI-38 cells and inhibition of oxidation by (a) S. oleraceus leaf extracts and (b) chlorogenic acid with time. The fluorescence intensity indicates the oxidation of DCFH. The curves shown in each graph are from a single experiment (mean $+\mathrm{SD}, n=3$ ).

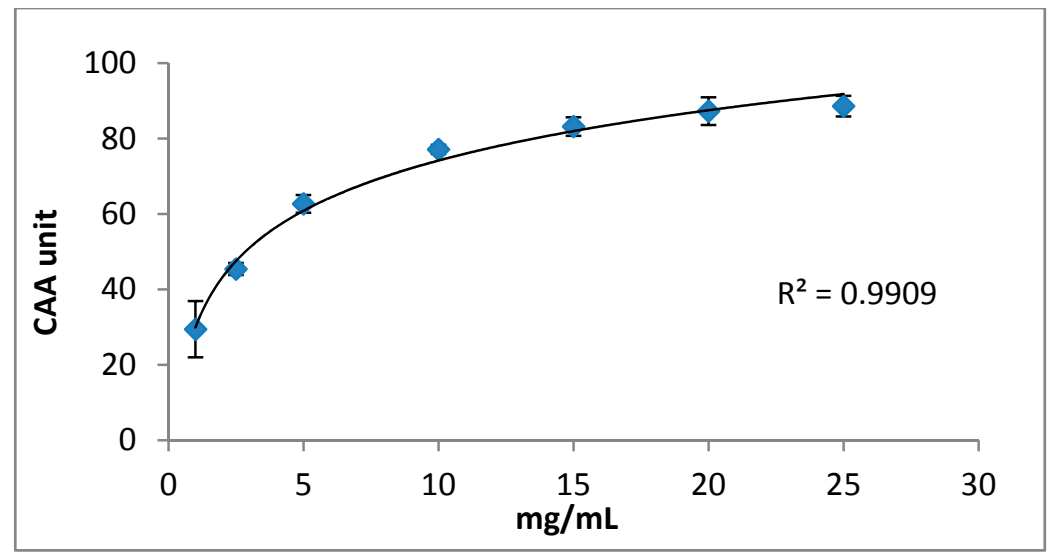

(a)

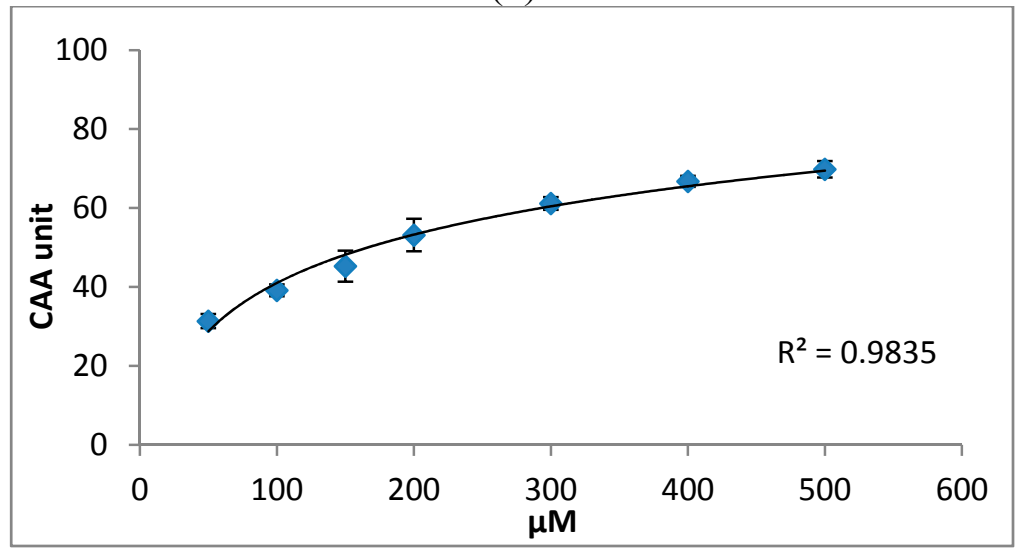

(b)

Figure 3. Dose-response curves for inhibition of peroxyl radical-induced DCFH oxidation by (a) S. oleraceus leaf extracts and (b) chlorogenic acid. The data were expressed as CAA unit indicating the intra-cellular antioxidant activity of samples. The curves shown are each from a single experiment (mean $\pm \mathrm{SD}, n=3$ ). 


\subsection{Effects of S. oleraceus Leaf Extracts on Stress-Induced Premature Senescence in WI-38 Cells}

\subsubsection{Protective Effect}

The SA- $\beta$-Gal positive cell population increased significantly $(p<0.01)$ from $24.6 \pm 1.6$ to $57.4 \% \pm 8.1 \%$ after being stressed with $100 \mu \mathrm{M} \mathrm{H}_{2} \mathrm{O}_{2}$ (Figure 4). There was a concentration-dependent effect of the $S$. oleraceus leaf extracts on the proportion of SA- $\beta$-Gal positive cells (Figure 4 ), and a trend for pre-treatment with $1 \mathrm{mg} / \mathrm{mL}$ S. oleraceus leaf extracts to reduce the percentage of SA- $\beta$-Gal positive cells. At $5 \mathrm{mg} / \mathrm{mL}, S$. oleraceus leaf extracts reduced two thirds of $\mathrm{H}_{2} \mathrm{O}_{2}$ stress-induced SA- $\beta$-Gal activity. Stress-induced premature senescence was completely suppressed by $20 \mathrm{mg} / \mathrm{mL}$ S. oleraceus leaf extracts and was equivalent to the control group that did not receive the $\mathrm{H}_{2} \mathrm{O}_{2}$ stress (Figure 4). Compared to cells with corresponding ascorbic acid treatments (88 and $352 \mu \mathrm{M}), 5$ and $20 \mathrm{mg} / \mathrm{mL}$ S. oleraceus leaf extracts had a tendency to show better protective effects, but these data were not statistically significant.

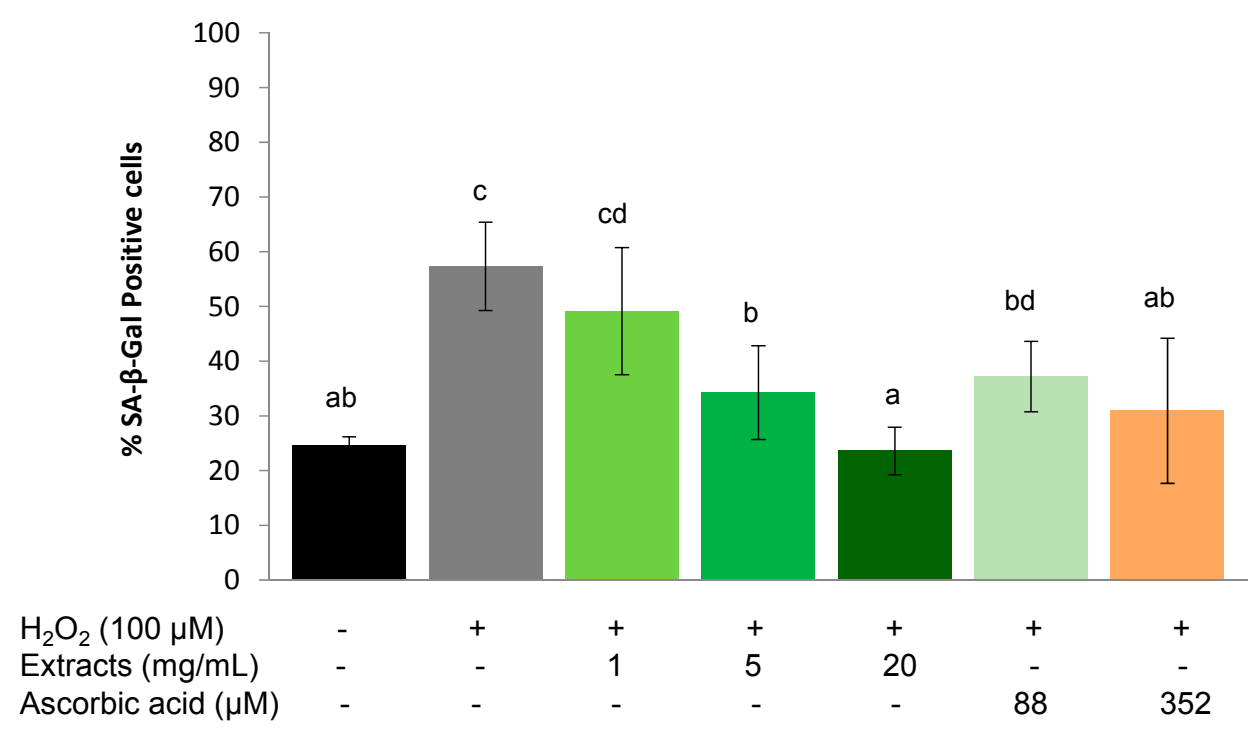

Figure 4. Protective effect of $S$. oleraceus leaf extracts on $\mathrm{H}_{2} \mathrm{O}_{2}$ treated WI-38 cells. Cells were treated with 1,5 or $20 \mathrm{mg} / \mathrm{mL}$ S. oleraceus leaf extracts or 88 or $352 \mu \mathrm{M}$ ascorbic acid for $1 \mathrm{~h}$ before being stressed with $100 \mu \mathrm{M} \mathrm{H}_{2} \mathrm{O}_{2}$. Data are shown as percentage of SA- $\beta$-Gal positive cells (mean $\pm \mathrm{SD}, n=6$ ). Bars with no letters in common are significantly different $(p<0.05)$.

\subsubsection{Recovery Effect}

A similar trend as for the protective effect was observed for the ability of $S$. oleraceus extracts to assist in the recovery of WI-38 cells from the application of exogenous stress. $1 \mathrm{~h}$ treatment with $100 \mu \mathrm{M} \mathrm{H}_{2} \mathrm{O}_{2}$ significantly $(p<0.01)$ increased SA- $\beta$-Gal positive cells from $21.55 \% \pm 4.12 \%$ to $33.40 \% \pm 4.25 \%$. However, this increase was lower than that of $\mathrm{H}_{2} \mathrm{O}_{2}$ treatment in the protective experiment (Figure 4). S. oleraceus extracts (except $1 \mathrm{mg} / \mathrm{mL}$ ) and ascorbic acid reduced the SA- $\beta$-Gal activity caused by $\mathrm{H}_{2} \mathrm{O}_{2}$, and showed a concentration-dependent effect. When the concentration of $S$. oleraceus extracts was increased to 5 or $20 \mathrm{mg} / \mathrm{mL}$, SA- $\beta$-Gal activity induced by $\mathrm{H}_{2} \mathrm{O}_{2}$ was significantly $(p<0.05)$ reduced. 
Furthermore, 5 and $20 \mathrm{mg} / \mathrm{mL}$ S. oleraceus extracts showed significantly $(p<0.05)$ better recovery ability than the corresponding ascorbic acid treatments, although $352 \mu \mathrm{M}$ ascorbic acid also significantly reduced the SA- $\beta$-Gal activity $(p<0.01)$ compared to $\mathrm{H}_{2} \mathrm{O}_{2}$ stress (Figure 5).

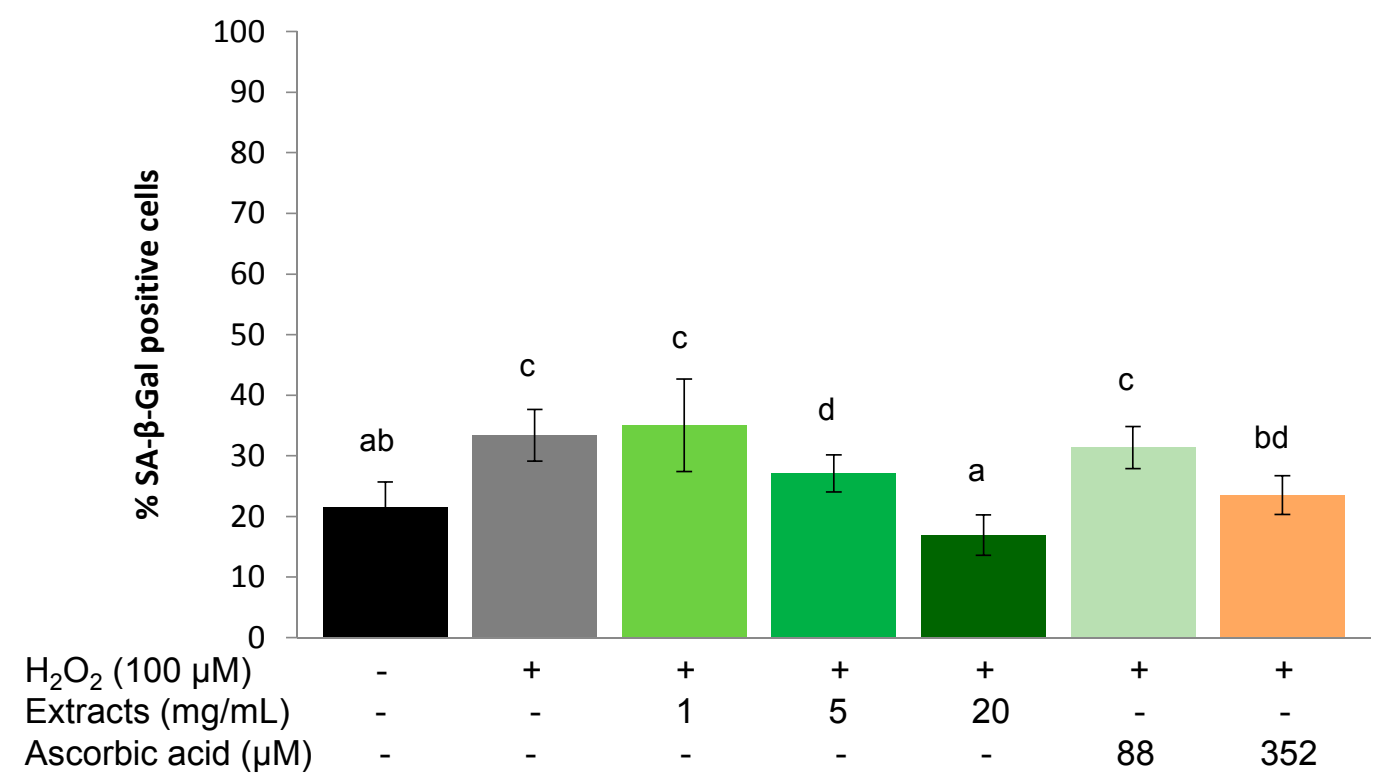

Figure 5. Recovery effect of $S$. oleraceus leaf extracts on $\mathrm{H}_{2} \mathrm{O}_{2}$ treated WI-38 cells. Cells were treated with 1,5 or $20 \mathrm{mg} / \mathrm{mL}$ S. oleraceus leaf extracts or 88 or $352 \mu \mathrm{M}$ ascorbic acid for $1 \mathrm{~h}$ following a $1 \mathrm{~h}$ incubation with $100 \mu \mathrm{M} \mathrm{H}_{2} \mathrm{O}_{2}$ as exogenous stress. Data are shown as percentage of SA- $\beta$-Gal positive cells (mean $\pm \mathrm{SD}, n=6$ ). Bars with no letters in common are significantly different $(p<0.05)$.

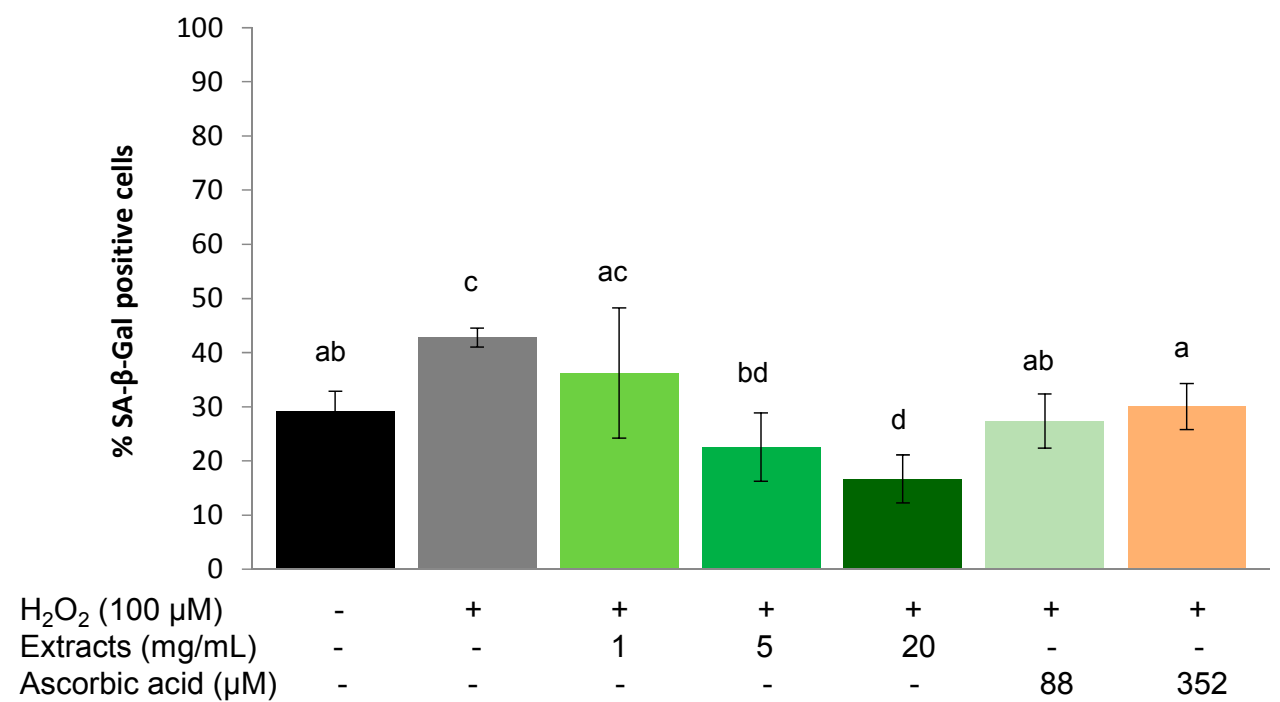

Figure 6. Protective effect of $S$. oleraceus leaf extracts on WI-38 cells chronically treated with $\mathrm{H}_{2} \mathrm{O}_{2}$. Cells were treated with 1,5 or $20 \mathrm{mg} / \mathrm{mL}$ S. oleraceus leaf extracts or 88 or $352 \mu \mathrm{M}$ ascorbic acid for $1 \mathrm{~h}$ at day 1 before being stressed with $30 \mu \mathrm{M} \mathrm{H}_{2} \mathrm{O}_{2} 1 \mathrm{~h}$ per day for five consecutive days. Data are shown as percentage of SA- $\beta$-Gal positive cells (mean $\pm \mathrm{SD}$, $n=6)$. Bars with no letters in common are significantly different $(p<0.05)$. 


\subsubsection{Protective Effect on Chronic Stress}

SA- $\beta$-Gal positive cells increased significantly $(p<0.01)$ after consecutive stress of $30 \mu \mathrm{M}$ of $\mathrm{H}_{2} \mathrm{O}_{2}$ each day for 5 days (Figure 6). $1 \mathrm{~h}$ treatment with $S$. oleraceus leaf extracts (except $1 \mathrm{mg} / \mathrm{mL}$ ) or ascorbic acid significantly reduced the SA- $\beta$-Gal positive cell population, indicating a sustained protective effect of one acute dose of these antioxidants from repeated exposure to low $\mathrm{H}_{2} \mathrm{O}_{2}$ levels (Figure 6). In line with the acute protective and recovery effects, a concentration-dependent effect of $S$. oleraceus leaf extracts was also observed (Figure 6). The highest concentration of $S$. oleraceus leaf extracts tested was also more effective at reducing SA- $\beta$-Gal activity than the equivalent ascorbic acid treatment.

\subsection{Discussion}

There is growing interest in the use of natural antioxidants for human health benefits or even as food preservatives due to the safety issues raised by the use of synthetic antioxidants [33]. Many natural products have been reported to have anti-ageing activity, including herbal extracts such as Rhodiola rosea (Crassulaceae), Rosa damascene (Rosaceae), Damnacanthus officinarum (Rubiaceae), spinach leaf and green tea extracts [34]. S. oleraceus, a traditional medicinal plant worldwide, is well-known for its high antioxidant content. It is reported that $S$. oleraceus leaf extracts are non-cytotoxic on HepG2 cells below a concentration of $100 \mathrm{mg} / \mathrm{mL}$ [30]. To our knowledge, there is no report on the application of $S$. oleraceus leaf extracts on normal human diploid cells. In the present study, no cytotoxicity of S. oleraceus leaf extracts up to $100 \mathrm{mg} / \mathrm{mL}$ was observed in WI-38 cells (Figure 1).

The measurement of antioxidant activity is an important part of screening plant extracts that have the potential to be developed into supplements. Previously, we reported high antioxidant activity of $S$. oleraceus leaf extracts determined by the DPPH free radical assay [30,35]. However, a high antioxidant activity as measured by in vitro chemical assays does not necessarily correlate to relevant in vivo activity because of the limited predictability in complex biological systems. For instance, extracts from plum fruit had the same chemical antioxidant activity using the ORAC assay as blackberry extracts, but significantly lower cellular activity than blackberry extracts [36]. Nevertheless, some studies do show some correlations between chemical and cellular measurements of antioxidant activity of plant samples [37,38]. Cellular antioxidant activity is an important and useful parameter that indicates antioxidant activity of samples, and is more biologically representative compared to test tube chemical antioxidant activity measurements. The CAA assay developed by Wolfe and Liu [32] utilizes peroxyl radicals to assess antioxidant activity and takes into account cellular uptake, distribution and metabolism by incubating cells with antioxidants prior to exogenous application of oxidative stress. Using this assay in the present study, it is observed that $S$. oleraceus leaf extracts were absorbed by and exhibited antioxidant activity in WI-38 cells with an $\mathrm{EC}_{50}$ value of $2.85 \mathrm{mg} / \mathrm{mL}$ (Figure 2). This activity is lower than the reported value for blueberry $(10.81 \mathrm{mg} / \mathrm{mL})$ [32]. This indicates the high potency of $S$. oleraceus extracts, with values also higher than a range of vegetables [39], including broccoli, lettuce and tomatoe; and a range of other fruits [36], including apple and kiwifruit. $1 \mathrm{mg} / \mathrm{mL}$ S. oleraceus leaf extracts with $17.6 \mu \mathrm{M}$ of the total key antioxidants had a comparably high activity to that of $50 \mu \mathrm{M}$ chlorogenic acid, suggesting that the antioxidant extract matrix is more effective than chlorogenic acid alone. It is also possible that chlorogenic acid is not the major contributor to the cellular activity of $S$. oleraceus leaf extract. 
Ageing is inevitable, but processes that are induced by external factors can be slowed by down-regulating oxidative stress in the body, for instance, by supplementing with antioxidants. Hwang et al. [13] demonstrated that ascorbic acid extends the replicative life span of human embryonic fibroblasts by decreasing cellular ROS to reduce mitochondrial and DNA damage. In the present study, ascorbic acid and $S$. oleraceus extracts containing an antioxidant mixture also exhibited an anti-ageing effect by reducing stress-induced premature senescence (Figures 4-6). However, long-term ascorbic acid supplementation has shown conflicting effects in animal studies. A diet of an antioxidant combination showed no increase in the life span of rats [40]. The authors proposed that compensatory reductions in endogenous protection mechanisms might be involved when high dietary doses of vitamin $\mathrm{C}$ were administered. For this reason, the concentration of ascorbic acid used for the present study has been carefully chosen. Cells with stress-induced, premature senescence share similar characteristics to those with replicative senescence, such as morphology, cell cycle regulation, increased ROS generation and SA- $\beta$-gal activity [2]. Stress-induced premature senescence can be induced by various sub-lethal stresses including $\mathrm{H}_{2} \mathrm{O}_{2}$, hyperoxia, UV radication or tert-butylhydroperoxide [2,9,41]. Human fibroblasts undergo finite proliferation before irreversible growth arrest in vitro [42]. Human diploid fibroblasts have become a classical model for studying cellular ageing and identifying ageing-related changes in human cells. Based on these features, $\mathrm{H}_{2} \mathrm{O}_{2}$ stressed human fibroblast cells are considered a suitable model to assess effects of anti-ageing agents $[9,19,43]$. SA- $\beta$-gal activity is one of the most popular biomarkers for cell senescence $[44,45]$. The SA- $\beta$-gal activity in the present study increased significantly in the presence of $\mathrm{H}_{2} \mathrm{O}_{2}$, suggesting that cells experienced senescence. Both $S$. oleraceus extracts and ascorbic acid suppressed SA- $\beta$-gal activity caused by $\mathrm{H}_{2} \mathrm{O}_{2}$, indicating the anti-senescence properties of $S$. oleraceus extracts and ascorbic acid. 88 and $352 \mu \mathrm{M}$ ascorbic acid (equivalent to 5 and $20 \mathrm{mg} / \mathrm{mL} S$. oleraceus extracts, respectively) did not show better ability than the corresponding $S$. oleraceus extracts. This implied that $S$. oleraceus extracts at a concentration of $20 \mathrm{mg} / \mathrm{mL}$ and above might have better ability of protecting or recovering stress-induced premature senescence than ascorbic acid.

From the above, it is clear that $S$. oleraceus leaf extracts can protect human cells from stress-induced senescence. However, if this effect is long lasting or if frequent treatments are required to maintain this effect remain unknown. In view of this, a chronic stress experiment was carried out to further explore the anti-ageing effect of $S$. oleraceus leaf extracts. The results demonstrated a similar effect pattern as that of acute stresses (Figure 6). This suggested that S. oleraceus extracts can not only assist cells to recover from acute $\mathrm{H}_{2} \mathrm{O}_{2}$ stress, but can also protect cells from chronic stress applied for five consecutive days as tested in the present study. Similar to the present results, a mixture of cocoa and green tea extracts, rich in polyphenols, and vitamin E significantly reduced UV stress-induced premature senescence from $51.67 \%$ to $38.81 \%$ in human dermal fibroblasts [46]. Oxidative DNA damage has been demonstrated to be proportional to the age of WI-38 human fibroblast cells [9] and was proposed to be another biomarker for cellular senescence. $\mathrm{H}_{2} \mathrm{O}_{2}$-induced DNA damage [43] thus showed senescent-like growth arrest [47] in human fibroblasts. In accordance with previous studies, despite the use of a different biomarker in the present study, $\mathrm{H}_{2} \mathrm{O}_{2}$ significantly increased stress-induced premature senescence (Figures 4-6). It is reported that antioxidant treatments counteracted the effect of stressors, including $\mathrm{H}_{2} \mathrm{O}_{2}$, and restored DNA synthesis [48]; and therefore can protect the cells from premature ageing. Further studies are needed to understand how $S$. oleraceus leaf extracts mediate the effects of the external stress factors on cells. For example, utilizing the comet assay [49] to characterize the extent of DNA damage. An 
understanding of the cellular components that are damaged by application of stress would help to define which of the cellular processes are involved during recovery from stress.

The protective and recovery ability of $S$. oleraceus extracts against $\mathrm{H}_{2} \mathrm{O}_{2}$ stress-induced premature senescence in the present study was encouraging for the use of $S$. oleraceus leaves as a potent anti-ageing, nutritional supplement. In the development of oral supplements, it is imperative to characterize the in vivo stability of bioactive components in the gastrointestinal tract environment. Further, to ensure the therapeutic effect of the $S$. oleraceus leaf extracts following oral administration, formulation strategies that increase the in vivo stability, absorption and bioavailability should be investigated.

\section{Experimental Section}

\subsection{Plant Material}

S. oleraceus seeds were collected from plants growing wild in Oamaru, New Zealand $\left(45^{\circ} 05.346^{\prime} \mathrm{S}\right.$, $\left.170^{\circ} 58.861^{\prime} \mathrm{E}\right)$ and identified by Mr John Steel, a botanist in the Department of Botany at the University of Otago, New Zealand. Voucher specimens (OTA 061166 and OTA 061167) are lodged at the Otago Regional Herbarium in the Department of Botany at the University of Otago, New Zealand. Seeds were germinated in a 50:50 potting compost:sand mix and grown for three weeks in a greenhouse, and the seedlings transplanted into $1 \mathrm{~L}$ pots in the same soil mix as above. Tap water was supplied every two days. Artificial light was provided $24 \mathrm{~h}$ a day in addition to normal natural daylight. The temperature inside the greenhouse was maintained at $25^{\circ} \mathrm{C}$. Fully expanded mature leaves from the middle of eight-week-old S. oleraceus plants were harvested and freeze-dried before being blended into a powder.

\subsection{Preparation of Leaf Extracts}

Freeze-dried $S$. oleraceus leaf powder was extracted with $70 \%$ methanol $(v / v)$ to obtain a $10 \%$ (fresh $w / v$ ) mixture as described by Ou et al. [31]. After stirring for approximately $0.5 \mathrm{~h}$ at room temperature, the extraction mixture was centrifuged at $9700 \mathrm{~g}$ for $10 \mathrm{~min}$. Solvent was removed by centrifugal evaporation (SVC-200H SpeedVac ${ }^{\circledR}$ Concentrator, Savant, Farmingdale, NY, USA). The dried extracts were stored at $-20{ }^{\circ} \mathrm{C}$ before further analysis.

\subsection{Preparation of Extract Samples and Chemical Solutions}

S. oleraceus extracts were prepared from freeze-dried leaf powder as described above. Chlorogenic acid (99\% GR) (Acros Organics, Geel, Belgium) and ascorbic acid (Sigma ${ }^{\circledR}$, St. Louis, MO, USA) and extract solutions were prepared immediately prior to use. For cytotxicity measurements, methylene blue stain solution consisted of $98 \%$ HBSS $(v / v), 0.5 \%$ glutaraldehyde and $0.6 \%$ methylene blue $(w / v)$ (Koch-Light laboratories Ltd., UK). Elution solution was made of $49 \%$ phosphate buffered saline solution (PBS) $\left(\right.$ Gibco $^{\circledR}$, Grand Island, NY, USA), 50\% ethanol and 1\% acetic acid ( $\left.v / v\right)\left(\right.$ BDH Aristar ${ }^{\circledR}$, Edmonton, AB, Canada).

For the Cellular Antioxidant Activity (CAA) assay, a $20 \mathrm{mM}$ stock solution of 2',7'-dichloro-fluorescin diacetate (DCFH-DA) $\left(\right.$ Sigma $^{\circledR}$, Rehovot, Israel) in methanol was prepared and stored at $-20^{\circ} \mathrm{C}$. A $200 \mathrm{mM}$ 2,2'-azobis(2-methylpropionamidine) dihydrochloride (ABAP) (Sigma ${ }^{\circledR}$ ) stock solution in Hank's balanced salt solution (HBSS) $\left(\right.$ Sigma $^{\circledR}$ ) was prepared, and aliquots were stored at $-20{ }^{\circ} \mathrm{C}$. Chlorogenic 
acid was dissolved in purified water before further dilution in treatment medium (Basal Medium Eagle (BME) $\left(\right.$ Gibco $\left.^{\circledR}\right)$ with $2 \mathrm{mM}$ GlutaMAX $\left(\right.$ Gibco $\left.^{\circledR}\right)$ and $25 \mathrm{mM}$ 2-[4-(2-hydroxyethyl)piperazin-1yl]ethanesulfonic acid (HEPES) (Sigma $\left.{ }^{\circledR}\right)$. Dried $S$. oleraceus extracts were re-dissolved and further diluted to required working concentrations in treatment medium.

For the ageing study, dried leaf extracts were re-dissolved in treatment media resulting in a concentration of $100 \mathrm{mg} / \mathrm{mL}$ (fresh weight). $1 \mathrm{mM}$ stock solution of ascorbic acid was prepared in purified ionized water immediately prior to experiments. The filtered $S$. oleraceus extracts and ascorbic acid stock solution were further diluted in treatment media to working concentrations. $30 \% \mathrm{H}_{2} \mathrm{O}_{2}$ was diluted to required working concentrations using treatment media. Bafilomycin A1 (>95\%) (Merck Sydney, Australia) was dissolved in dimethyl sulfoxide (DMSO) (Sigma ${ }^{\circledR}$, Lyon, France) to a final concentration of $0.1 \mathrm{mM}$. For experimental application, the bafilomycin A1 stock was diluted to $100 \mathrm{nM}$ in cBME (BME supplemented with 10\% Fetal bovine serum (FBS) (Gibco ${ }^{\circledR}$, Auckland, New Zealand), 2 mM GlutaMAX plus $25 \mathrm{mM}$ HEPES, pH 7.2). 5-Dodecanoylaminofluorescein Di- $\beta$-D-galacto-pyranoside ( $\left.\mathrm{C}_{12} \mathrm{FDG}\right)$ (Setareh Biotech, Eugene, OR, USA) stock solution was also prepared in DMSO to a final concentration of $20 \mathrm{mM}$. The $20 \mathrm{mM}$ stock solution of $\mathrm{C}_{12} \mathrm{FDG}$ was diluted 1:10 with fresh cBME to make a $2 \mathrm{mM}$ working solution immediately before its addition into the cells. The final concentration of $\mathrm{C}_{12} \mathrm{FDG}$ obtained in cells was $33 \mu \mathrm{M}$. Fluorescence-activated cell sorting (FACS) buffer was prepared by dissolved $1 \%(w / v)$ bovine serum albumin $\left(\right.$ Gibco $^{\circledR}$, New Zealand) and $0.01 \%(w / v)$ sodium azide (Sigma ${ }^{\circledR}$ ) in PBS.

\subsection{Cell Culture}

WI-38 human lung diploid fibroblast cells (Coriell Cell Repositories, Camden, NJ, USA) were cultured in cBME at $37{ }^{\circ} \mathrm{C}$ with $5 \% \mathrm{CO}_{2}$. The medium was changed every $3-4$ days. Cells used for this study were at population doubling level (PDL) 19-27. The PDL of the cell culture was determined as follows: current PDL $=$ last PDL $+3.32 \times \log$ (harvested cell population/seeded cell population).

\subsection{Cell Viability}

Cell viability was measured using the method of Wolfe et al. [32] with modifications. WI-38 cells were seeded in a 96-well plate at a density of $5 \times 10^{4}$ cells per $\mathrm{cm}^{2}$ and cultured in cBME. After $24 \mathrm{~h}$ incubation, cells were treated with various concentrations of $S$. oleraceus extracts or ascorbic acid in treatment media for $3 \mathrm{~h}$ or $24 \mathrm{~h}$, or treated with $\mathrm{H}_{2} \mathrm{O}_{2}$ only for $2 \mathrm{~h}$. Cells were then washed with $100 \mu \mathrm{L}$ HBSS and $50 \mu \mathrm{L}$ methylene blue staining solution was added into each well. After another hour of incubation at $37{ }^{\circ} \mathrm{C}$, the dye was washed off using fresh deionized water and the plate was air-dried following elution.

\subsection{Cellular Antioxidant Activity (CAA) Assay}

The cellular antioxidant activity was measured using a modified method from Wolf et al. [32]. WI-38 cells were seeded at $5 \times 10^{4}$ cells per $\mathrm{cm}^{2}$ on a 96 -well plate in $100 \mu \mathrm{L}$ of cBME, excluding the outside wells of the plate. After incubation for $24 \mathrm{~h}$, the cBME was removed and the wells were washed with PBS. Triplicate wells were treated with $100 \mu \mathrm{L}$ of $S$. oleraceus extracts and $25 \mu \mathrm{M}$ DCFH-DA 
dissolved in treatment media and incubated for $1 \mathrm{~h}$. Cells were then washed with $100 \mu \mathrm{L}$ PBS, before $600 \mu \mathrm{M}$ ABAP was applied to the cells in $100 \mu \mathrm{L}$ of HBSS. Fluorescence was read with emission at $538 \mathrm{~nm}$ and excitation at $485 \mathrm{~nm}$ every $5 \mathrm{~min}$ for $1 \mathrm{~h}$ at $37^{\circ} \mathrm{C}$ (POLARstar Omega microplate reader, BMG Labtech, Cary, NC, USA).

\subsection{Quantification of CAA}

After blank subtraction from the fluorescence readings, the area under the curve of fluorescence versus time was integrated to calculate the CAA unit as:

$$
\text { CAA unit }=100-\left(\int \mathrm{SA} / \int \mathrm{CA}\right) \times 100
$$

where $\int \mathrm{SA}$ and $\int \mathrm{CA}$ are the integrated areas under the curve of sample and control, respectively [32]. The median effective concentration $\left(\mathrm{EC}_{50}\right)$ was determined for the $S$. oleraceus extracts and chlorogenic acid from the dose-response curve where the CAA unit is equal to 50 .

\subsection{Stress-Induced Premature Senescence in WI-38 Cells}

\subsubsection{Protective Effect of S. oleraceus Leaf Extracts}

To investigate if $S$. oleraceus leaf extracts can protect human cells from exposure to oxidative stress, WI-38 cells were seeded at a density of $5 \times 10^{4}$ cells per $\mathrm{cm}^{2}$ in a 24 -well plate. After $24 \mathrm{~h}$ incubation, cells were treated with 1,5 or $20 \mathrm{mg} / \mathrm{mL}$ (fresh weight) $S$. oleraceus leaf extracts or 88 or $352 \mu \mathrm{M}$ ascorbic acid in treatment media for $1 \mathrm{~h} .88$ or $352 \mu \mathrm{M}$ ascorbic acid were chosen as the equivalent concentrations to the total concentrations of the three key antioxidants in 5 and $20 \mathrm{mg} / \mathrm{mL}$ extracts, respectively. Then cells were washed with HBSS before being stressed with $100 \mu \mathrm{M} \mathrm{H}_{2} \mathrm{O}_{2}$ in treatment media for another $1 \mathrm{~h}$. Fresh cBME was added after the cells were washed with HBSS. Cells without any treatment were used as unstained controls. Cells with $\mathrm{H}_{2} \mathrm{O}_{2}$ treatment only were used as positive controls. After $48 \mathrm{~h}$ rest from stress, cells were treated for FACS measurement as detailed below.

\subsubsection{Recovery Ability of S. oleraceus Leaf Extracts}

The recovery ability of $S$. oleraceus leaf extracts was conducted in the same way as the protective effect study described above with one modification: WI-38 cells were stressed with $100 \mu \mathrm{M} \mathrm{H}_{2} \mathrm{O}_{2}$ for $1 \mathrm{~h}$ before being treated with 1,5 or $20 \mathrm{mg} / \mathrm{mL}$ (fresh weight) $S$. oleraceus leaf extracts or 88 or $352 \mu \mathrm{M}$ ascorbic acid.

\subsubsection{Protective Effect from Chronic Stress}

WI-38 cells were treated for $1 \mathrm{~h}$ with 1,5 or $20 \mathrm{mg} / \mathrm{mL}$ (fresh weight) S. oleraceus leaf extracts or 80 or $352 \mu \mathrm{M}$ ascorbic acid before chronic stress. Chronic stress was applied by adding $30 \mu \mathrm{M}$ of $\mathrm{H}_{2} \mathrm{O}_{2}$ for $1 \mathrm{~h}$ per day 5 days after a single treatment of $S$. oleraceus leaf extracts or ascorbic acid. General procedures were otherwise the same as described above in the protective effect experiment. 


\subsection{Analysis of Senescence-Associated $\beta$-Galactosidase (SA- $\beta$-gal) Activity in WI-38 Cells}

The SA- $\beta$-gal activity was determined as described by Debacq-Chainiaux et al. [3] with modifications. After $48 \mathrm{~h}$ rest from stress, cells in 24-well plates were treated with $100 \mathrm{nM}$ bafilomycin $\mathrm{A} 1$ for $1 \mathrm{~h}$ in fresh cBME $(0.5 \mathrm{~mL})$ at $37{ }^{\circ} \mathrm{C}$ to induce lysosomal alkalinisation to facilitate measurement of the SA- $\beta$-gal activity at $\mathrm{pH}$ 6. $8.25 \mu \mathrm{L}$ of $2 \mathrm{mM} \mathrm{C}{ }_{12} \mathrm{FDG}$ working solution $\left(\mathrm{C}_{12} \mathrm{FDG}\right.$ is a fluorogenic membrane-permeable substrate of $\beta$-galactosidase) was added to the media to give a final concentration of approximately $33 \mu \mathrm{M}$ and the incubation was continued for another $1 \mathrm{~h}$. The solution was removed and the cell monolayers were washed twice for approximately $30 \mathrm{~s}$ with $0.5 \mathrm{~mL}$ of PBS at room temperature. Cells were then trypsinized (TrypLE $\left.{ }^{\mathrm{TM}}\right)\left(\mathrm{Gibco}^{\circledR}\right)$ and harvested followed by centrifugation at $100 \mathrm{~g}$ for $10 \mathrm{~min}$ at $4{ }^{\circ} \mathrm{C}$. Cells were re-suspended in ice-cold FACS buffer and analysed immediately in a FACScalibur flow cytometer (FACSCanto II, Becton Dickinson, Franklin Lakes, NJ, USA). FlowJo software (Version 9.5.2, TreeStar, Inc., Ashland, OR, USA) was used for data analysis. Propidium iodide (BD Biosciences, San Jose, CA, USA) was used as dead/living cell indicator for all the cell samples.

\subsection{Statistics}

Either a Student's $t$-test using Microsoft Excel (Version 2007) or analysis of variance with post-hoc Tukey's multiple comparisons using SPSS Statistics from IBM (International Business Machines Corp., Armonk, NY, USA, Version 20) were used to establish significant differences between the groups. $p$-values $<0.05$ were considered to be significant.

\section{Conclusions}

In summary, our results demonstrate that $S$. oleraceus extracts possessed high cellular antioxidant activity, compared to chlorogenic acid or other plant samples reported in literature. $\mathrm{H}_{2} \mathrm{O}_{2}$ stress-induced premature senescence can be significantly suppressed by $S$. oleraceus extracts at $5 \mathrm{mg} / \mathrm{mL}$ or above, and this anti-ageing effect is concentration-dependent. When compared to the corresponding ascorbic acid treatments, 5 and $20 \mathrm{mg} / \mathrm{mL} S$. oleraceus extracts showed better or equivalent effects. These data suggest the therapeutic potential of $S$. oleraceus extracts as an anti-ageing agent.

\section{Acknowledgments}

The authors thank New Zealand Pharmacy Education Research Fund for the financial support. The authors wish to express their sincere appreciation to Kevin Gould for supply of the seeds and Susan McKenzie, Department of Botany, University of Otago, for helping with growing the plants.

\section{Author Contributions}

A.McD. and T.R. conceived and designed the experiments; performed the experiments; Z.Q.O. and A.McD. analyzed the data; Z.Q.O., A.McD. and T.R. wrote the paper. All authors have read and approved this manuscript. 


\section{Conflicts of Interest}

The authors declare no conflict of interest.

\section{References}

1. Getoff, N. Anti-aging and aging factors in life. The role of free radicals. Radiat. Phys. Chem. 2007, $76,1577-1586$.

2. Toussaint, O.; Medrano, E.E.; von Zglinicki, T. Cellular and molecular mechanisms of stress-induced premature senescence (sips) of human diploid fibroblasts and melanocytes. Exp. Gerontol. 2000, $35,927-945$.

3. Debacq-Chainiaux, F.; Erusalimsky, J.D.; Campisi, J.; Toussaint, O. Protocols to detect senescence-associated beta-galactosidase (SA- $\beta$-gal) activity, a biomarker of senescent cells in culture and in vivo. Nat. Protoc. 2009, 4, 1798-1806.

4. Von Zglinicki, T. Role of oxidative stress in telomere length regulation and replicative senescence. Annu. N. Y. Acad. Sci. 2000, 908, 99-110.

5. Halliwell, B.; Gutteridge, J.M.C. Free Radicals in Biology and Medicine, 4th ed.; Oxford University Press: New York, NY, USA, 2007.

6. Harman, D. Aging: A theory based on free radical and radiation chemistry. J. Gerontol. 1956, 11, 298-300.

7. Gutteridge, J.M.C.; Halliwell, B. Metals and oxygen: Respiration, oxidation and oxygen toxicity. In Antioxidants in Nutrition, Health, and Disease; Oxford University Press: Oxford, UK; New York, NY, USA, 1994; pp. 24-39.

8. Ames, B.N.; Shigenaga, M.K.; Hagen, T.M. Oxidants, antioxidants, and the degenerative diseases of aging. Proc. Natl. Acad. Sci. USA 1993, 90, 7915-7922.

9. Wolf, F.I.; Torsello, A.; Covacci, V.; Fasanella, S.; Montanari, M.; Boninsegna, A.; Cittadini, A. Oxidative DNA damage as a marker of aging in WI-38 human fibroblasts. Exp. Gerontol. 2002, 37 , 647-656.

10. Packer, L.; Smith, J.R. Extension of the lifespan of cultured normal human diploid cells by vitamin E. Proc. Natl. Acad. Sci. USA 1974, 71, 4763-4767.

11. Fusco, D.; Colloca, G.; Lo Monaco, M.R.; Cesari, M. Effects of antioxidant supplementation on the aging process. Clin. Interv. Aging 2007, 2, 377-387.

12. Masaki, H. Role of antioxidants in the skin: Anti-aging effects. J. Dermatol. Sci. 2010, 58, 85-90.

13. Hwang, W.-S.; Park, S.-H.; Kim, H.-S.; Kang, H.-J.; Kim, M.-J.; Oh, S.-J.; Park, J.-B.; Kim, J.; Kim, S.C.; Lee, J.-Y. Ascorbic acid extends replicative life span of human embryonic fibroblast by reducing DNA and mitochondrial damages. Nutr. Res. Pract. 2007, 1, 105-112.

14. Zhang, X.; Shi, G.F.; Liu, X.Z.; An, L.J.; Guan, S. Anti-ageing effects of protocatechuic acid from Alpinia on spleen and liver antioxidative system of senescent mice. Cell Biochem. Funct. 2011, 29, 342-347.

15. Wiegant, F.A.C.; Surinova, S.; Ytsma, E.; Langelaar-Makkinje, M.; Wikman, G.; Post, J.A. Plant adaptogens increase lifespan and stress resistance in C. elegans. Biogerontology 2009, 10, $27-42$. 
16. Yang, X.; Zhang, P.; Wu, J.; Xiong, S.; Jin, N.; Huang, Z. The neuroprotective and lifespan-extension activities of Damnacanthus officinarum extracts in Caenorhabditis elegans. J. Ethnopharmacol. 2012, 141, 41-47.

17. Fan, D.; Hodges, D.M.; Zhang, J.; Kirby, C.W.; Ji, X.; Locke, S.J.; Critchley, A.T.; Prithiviraj, B. Commercial extract of the brown seaweed Ascophyllum nodosum enhances phenolic antioxidant content of spinach (Spinacia oleracea L.) which protects Caenorhabditis elegans against oxidative and thermal stress. Food Chem. 2011, 124, 195-202.

18. Safer, A.M.; Al-Nughamish, A.J. Hepatotoxicity induced by the anti-oxidant food additive, butylated hydroxytoluene (BHT), in rats: An electron microscopical study. Histol. Histopathol. 1999, 14, 391-406.

19. Choi, M.J.; Kim, B.K.; Park, K.Y.; Yokozawa, T.; Song, Y.O.; Cho, E.J. Anti-aging effects of cyanidin under a stress-induced premature senescence cellular system. Biol. Pharm. Bull. 2010, 33, 421-426.

20. Noppe, G.; Dekker, P.; de Koning-Treurniet, C.; Blom, J.; van Heemst, D.; Dirks, R.W.; Tanke, H.J.; Westendorp, R.G.; Maier, A.B. Rapid flow cytometric method for measuring senescence associated $\beta$-galactosidase activity in human fibroblasts. Cytom. A 2009, 75, 910-916.

21. Hwang, E.; Yoon, G.; Kang, H. A comparative analysis of the cell biology of senescence and aging. Cell. Mol. Life Sci. 2009, 66, 2503-2524.

22. Von Zglinicki, T.; Saretzki, G.; Ladhoff, J.; D’Adda di Fagagna, F.; Jackson, S.P. Human cell senescence as a DNA damage response. Mech. Ageing Dev. 2005, 126, 111-117.

23. Debacq-Chainiaux, F.; Pascal, T.; Boilan, E.; Bastin, C.; Bauwens, E.; Toussaint, O. Screening of senescence-associated genes with specific DNA array reveals the role of IGFBP-3 in premature senescence of human diploid fibroblasts. Free Radic. Bio. Med. 2008, 44, 1817-1832.

24. Dimri, G.P.; Lee, X.; Basile, G.; Acosta, M.; Scott, G.; Roskelley, C.; Medrano, E.E.; Linskens, M.; Rubelj, I.; Pereira-Smith, O. A biomarker that identifies senescent human cells in culture and in aging skin in vivo. Proc. Natl. Acad. Sci. USA 1995, 92, 9363-9367.

25. Itahana, K.; Campisi, J.; Dimri, G. Methods to detect biomarkers of cellular senescence. In Biological Aging; Tollefsbol, T., Ed.; Humana Press: Totowa, NJ, USA, 2007; Volume 371, pp. 21-31.

26. Guil-Guerrero, J.L.; Gimenez-Gimenez, A.; Rodriguez-Garcia, I.; Torija-Isasa, M.E. Nutritional composition of Sonchus species (S. asper L., S. oleraceus L. and S. tenerrimus L.). J. Sci. Food Agric. 1998, 76, 628-632.

27. Yin, J.; Si, C.-L.; Wang, M.-H. Antioxidant activity of flavonoids and their glucosides from Sonchus oleraceus L. J. Appl. Biol. Chem. 2008, 51, 57-60.

28. Gould, K.S.; Thodey, K.; Philpott, M.; Ferguson, L.R. Antioxidant activities of extracts from traditional māori food plants. N. Z. J. Bot. 2006, 44, 1-4.

29. Xia, D.-Z.; Yu, X.-F.; Zhu, Z.-Y.; Zou, Z.-D. Antioxidant and antibacterial activity of six edible wild plants (Sonchus spp.) in china. Nat. Prod. Res. 2011, 25, 1893-1901.

30. McDowell, A.; Thompson, S.; Stark, M.; Ou, Z.-Q.; Gould, K.S. Antioxidant activity of puha (Sonchus oleraceus L.) as assessed by the cellular antioxidant activity (CAA) assay. Phytother. Res. 2011, 25, 1876-1882. 
31. Ou, Z.-Q.; Schmierer, D.M.; Rades, T.; Larsen, L.; McDowell, A. Application of an online post-column derivatization HPLC-DPPH assay to detect compounds responsible for antioxidant activity in Sonchus oleraceus L. leaf extracts. J. Pharm. Pharmacol. 2013, 65, 271-279.

32. Wolfe, K.L.; Liu, R.H. Cellular antioxidant activity (CAA) assay for assessing antioxidants, foods, and dietary supplements. J. Agric. Food Chem. 2007, 55, 8896-8907.

33. Yin, J.; Kwon, G.-J.; Wang, M.-H. The antioxidant and cytotoxic activities of Sonchus oleraceus L. extracts. Nutr. Res. Pract. 2007, 1, 189-194.

34. Argyropoulou, A.; Aligiannis, N.; Trougakos, I.P.; Skaltsounis, A.-L. Natural compounds with anti-ageing activity. Nat. Prod. Rep. 2013, 30, 1412-1437.

35. Ou, Z.-Q.; Schmierer, D.M.; Strachan, C.J.; Rades, T.; McDowell, A. Influence of postharvest processing and storage conditions on key antioxidants in pūhā (Sonchus oleraceus L.). J. Pharm. Pharmacol. 2014, 66, 998-1008.

36. Wolfe, K.L.; Kang, X.M.; He, X.J.; Dong, M.; Zhang, Q.Y.; Liu, R.H. Cellular antioxidant activity of common fruits. J. Agric. Food. Chem. 2008, 56, 8418-8426.

37. Eberhardt, M.V.; Kobira, K.; Keck, A.-S.; Juvik, J.A.; Jeffery, E.H. Correlation analyses of phytochemical composition, chemical, and cellular measures of antioxidant activity of broccoli (Brassica oleracea Var. Italica). J. Agric. Food Chem. 2005, 53, 7421-7431.

38. Roy, M.K.; Juneja, L.R.; Isobe, S.; Tsushida, T. Steam processed broccoli (Brassica oleracea) has higher antioxidant activity in chemical and cellular assay systems. Food Chem. 2009, 114, 263-269.

39. Song, W.; Derito, C.M.; Liu, M.K.; He, X.; Dong, M.; Liu, R.H. Cellular antioxidant activity of common vegetables. J. Agric. Food Chem. 2010, 58, 6621-6629.

40. Selman, C.; McLaren, J.S.; Meyer, C.; Duncan, J.S.; Redman, P.; Collins, A.R.; Duthie, G.G.; Speakman, J.R. Life-long vitamin C supplementation in combination with cold exposure does not affect oxidative damage or lifespan in mice, but decreases expression of antioxidant protection genes. Mech. Ageing Dev. 2006, 127, 897-904.

41. Debacq-Chainiaux, F.; Borlon, C.; Pascal, T.; Royer, V.; Eliaers, F.; Ninane, N.; Carrard, G.; Friguet, B.; de Longueville, F.; Boffe, S.; et al. Repeated exposure of human skin fibroblasts to UVB at subcytotoxic level triggers premature senescence through the TGF-betal signaling pathway. J. Cell Sci. 2005, 118, 743-758.

42. Hayflick, L.; Moorhead, P.S. The serial cultivation of human diploid cell strains. Exp. Cell Res. 1961, 25, 585-621.

43. Kang, K.A.; Lee, K.H.; Zhang, R.; Piao, M.J.; Chae, S.; Kim, K.N.; Jeon, Y.J.; Park, D.B.; You, H.J.; Kim, J.S.; et al. Caffeic acid protects hydrogen peroxide induced cell damage in WI-38 human lung fibroblast cells. Biol. Pharm. Bull. 2006, 29, 1820-1824.

44. Kurz, D.J.; Decary, S.; Hong, Y.; Erusalimsky, J.D. Senescence-associated (beta)-galactosidase reflects an increase in lysosomal mass during replicative ageing of human endothelial cells. J. Cell Sci. 2000, 113, 3613-3622.

45. Zhou, Y.; Dong, Y.; Xu, Q.G.; Zhu, S.Y.; Tian, S.L.; Huo, J.J.; Hao, T.T.; Zhu, B.W. Mussel oligopeptides protect human fibroblasts from hydrogen peroxide $\left(\mathrm{H}_{2} \mathrm{O}_{2}\right)$-induced premature senescence. Arch. Gerontol. Geriatr. 2014, 58, 293-299. 
46. Jorge, A.T.; Arroteia, K.F.; Lago, J.C.; de Sa-Rocha, V.M.; Gesztesi, J.; Moreira, P.L. A new potent natural antioxidant mixture provides global protection against oxidative skin cell damage. Int. J. Cosmet. Sci. 2011, 33, 113-119.

47. Chen, Q.M.; Bartholomew, J.C.; Campisi, J.; Acosta, M.; Reagan, J.D.; Ames, B.N. Molecular analysis of $\mathrm{H}_{2} \mathrm{O}_{2}$-induced senescent-like growth arrest in normal human fibroblasts: P53 and Rb control G1 arrest but not cell replication. Biochem. J. 1998, 332, 43-50.

48. San Miguel, S.M.; Opperman, L.A.; Allen, E.P.; Zielinski, J.; Svoboda, K.K.H. Bioactive polyphenol antioxidants protect oral fibroblasts from ROS-inducing agents. Arch. Oral. Biol. 2012, 57, $1657-1667$.

49. Collins, A.R.; Oscoz, A.A.; Brunborg, G.; Gaivao, I.; Giovannelli, L.; Kruszewski, M.; Smith, C.C.; Stetina, R. The comet assay: Topical issues. Mutagenesis 2008, 23, 143-151.

Sample Availability: Not available.

(C) 2015 by the authors; licensee MDPI, Basel, Switzerland. This article is an open access article distributed under the terms and conditions of the Creative Commons Attribution license (http://creativecommons.org/licenses/by/4.0/). 